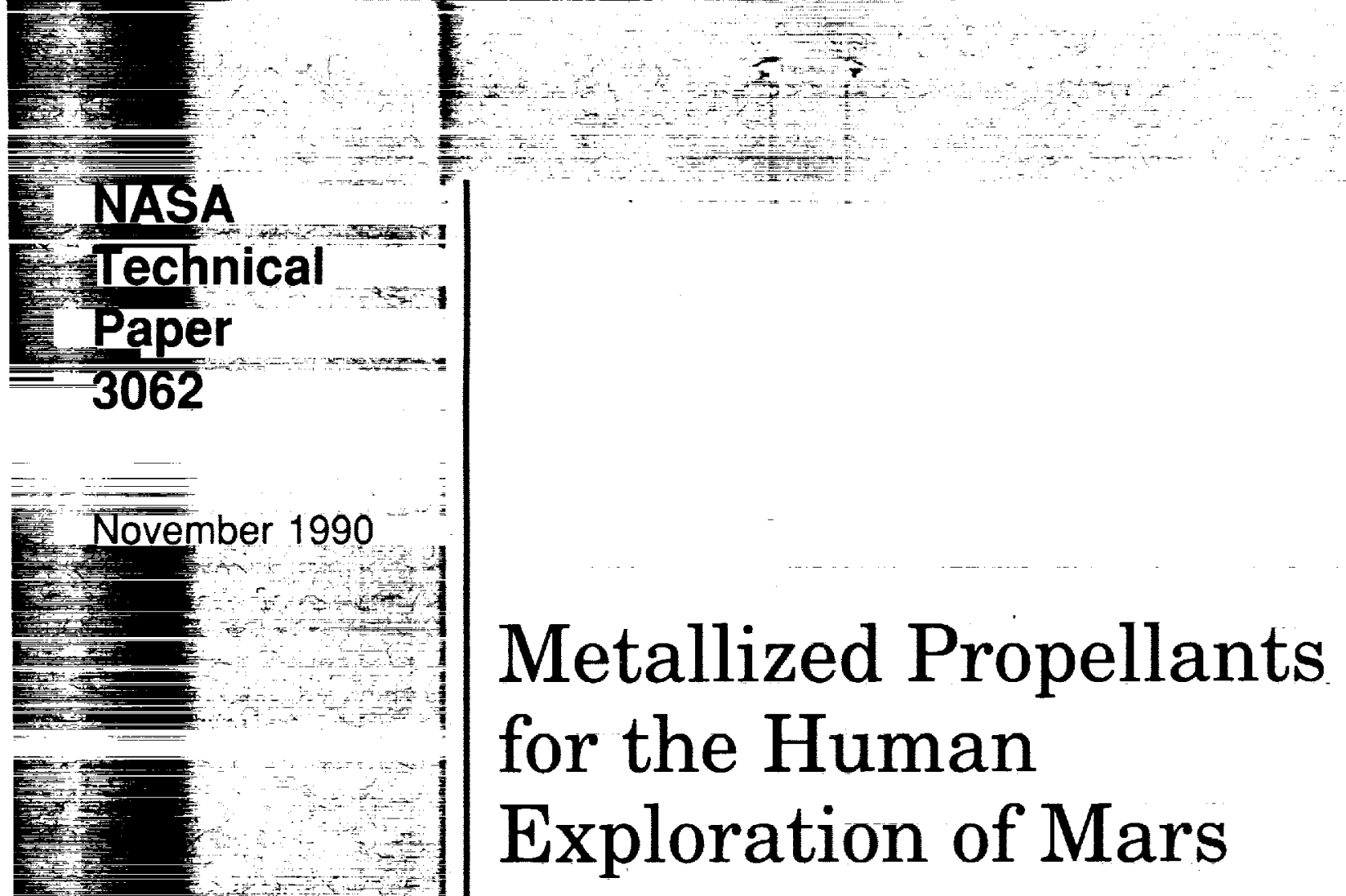

Metallized Propellants for the Human Exploration of Mars

Bryan A. Palaszewski

(NASA-YP-3O62) MITALLIZED PROPELLANTS FOR THE HUMAN EXPLORATION IJF MARS (NASA) $14 \mathrm{P}$ $N 1-11800$ CSCL $21 \mathrm{H}$ 


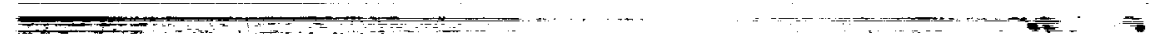

$+\frac{1}{-1}=-$

$=$

-

$=-\ldots-\ldots$

$\ldots$ 
NASA

Technical

Paper

3062

1990

\section{Metallized Propellants for the Human Exploration of Mars}

Bryan A. Palaszewski

Lewis Research Center

Cleveland, Ohio 


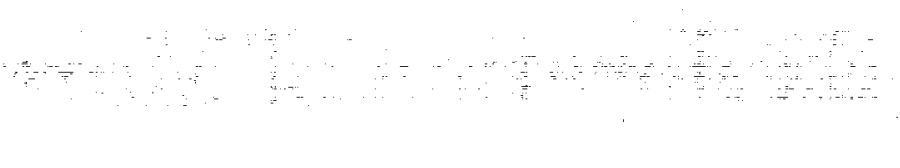




\section{Summary}

Advanced chemical propulsion using metallized propellants can lead to significant reductions in launch mass for piloted Mars missions. Metallized propellants allow the propellant density or the specific impulse $I_{s p}$ of the propulsion system, or both, to increase. Increasing propellant density and $I_{s p}$ can reduce the propellant mass and the propulsion system dry mass. These effects are discussed and analyzed in this report. Detailed mass-scaling equations and estimates of the $I_{s p}$ for several metallized propellant combinations are presented.

The most significant savings with metallized propellants are derived from increasing the payload delivered to Mars. For the same mass in low Earth orbit (LEO) ${ }^{1}$ a metallized Mars transfer vehicle can deliver 20 to 22 percent additional payload to the surface of Mars. Using metallized propulsion can accelerate the delivery and construction of a Mars base or outpost. This 20-percent payload increase reduces the total number of Mars flights and therefore significantly reduces the number of Space Transportation System-Cargo (STS-C) launches for the entire Mars architecture.

Using metallized propellants to reduce the mass in LEO per flight is not as effective as increasing the payload delivery capacity. Although over 20 percent more payload can be delivered to Mars per mission, the mass saving per flight (while delivering the same payload with a higher $-I_{s p}$ system) is much smaller. Using metallized propellants in all of the Mars propulsion systems would produce a modest 3.3-percent LEO mass saving. This translates into a saving of $38000 \mathrm{~kg}$ over the mass required with oxygen/hydrogen $\left(\mathrm{O}_{2} / \mathrm{H}_{2}\right)$ propulsion.

A Mars excursion vehicle using Earth- or space-storable propellants for the ascent can be an alternative to storing cryogenic $\mathrm{H}_{2}$ on Mars. There will be a mass penalty for using these alternatives because of the lower $I_{s p}$ of their propulsion systems. A space-storable system using oxygen/monomethyl hydrazine/aluminum $\left(\mathrm{O}_{2} / \mathrm{MMH} / \mathrm{Al}\right)$ would deliver the lowest mass penalty over $\mathrm{O}_{2} / \mathrm{H}_{2}$. For "expedition" missions the LEO mass penalty for using metallized $\mathrm{O}_{2} / \mathrm{MMH} / \mathrm{Al}$ would be only 3 to 5 percent.

\section{Introduction}

Over the past several years NASA has conducted many new studies of the missions that would send humans to the first

\footnotetext{
${ }^{\mathrm{I}}$ Acronyms are defined in the appendix.
}

landing on another planet (refs. 1 to 7). ${ }^{2}$ Human exploration of the solar system will require that large masses be transported to Earth orbit. The high-energy missions planned for Mars expeditions (using $\mathrm{O}_{2} / \mathrm{H}_{2}$ chemical propulsion on a sprint mission) require up to $1760000 \mathrm{~kg}$ in low Earth orbit (LEO) per flight.

In the Office of Exploration studies $\mathrm{O}_{2} / \mathrm{H}_{2}$ propulsion has been considered as the state-of-the-art system for all Mars missions (ref. 1). These studies, however, have shown that the mass in LEo is primarily the propulsion system. Figure 1 compares the masses of two fast "sprint" missions (with a 400-day round-trip) with those of lower-energy "evolution" and "expedition" Mars missions (with a 700- to 800-day round-trip). The propellant makes up 75 percent of the mass in LEO for the piloted sprint mission and 67 percent for the evolution mission. Even the low-energy vehicle for the cargo sprint mission has 55 percent of its mass invested in propellant (oxidizer and fuel).

These large propulsion systems are a major influence on the entire mission infrastructure: design, fabrication, launch, orbital assembly, flight, and recovery. In order to reduce this strong influence, advanced propulsion systems have been considered for these ambitious Mars missions. Advanced propulsion can either reduce the mass in LEO or allow a greater payload to be delivered to the final destination. This performance increase results from the higher specific impulse $I_{s p}$ of the propulsion system. Other benefits that can be derived from advanced propulsion are a reduction in the system's dry mass, a reduction in Mars outpost delivery and assembly time, or a reduction in mission complexity.

\section{Why Metallized Propellants?}

One advanced propulsion system that can provide benefits for Mars missions uses metallized propellants. These propellants offer increases in the overall propellant density or the $I_{s p}$ of a propulsion system, or both, significantly reducing the launch mass relative to conventional chemical propellants. Metallized propellants have metal added to the fuel or the oxidizer. Typically, the metal is in the form of micrometersized particles gelled with the $\mathrm{H}_{2}$ or other fuel to increase its

\footnotetext{
${ }^{2}$ And personal communications and analysis notes from A. Friedlander of Science Applications International Corp., Schaumberg, Illinois, and B. Donahue, Boeing Aerospace, Huntsville, Alabama.
} 


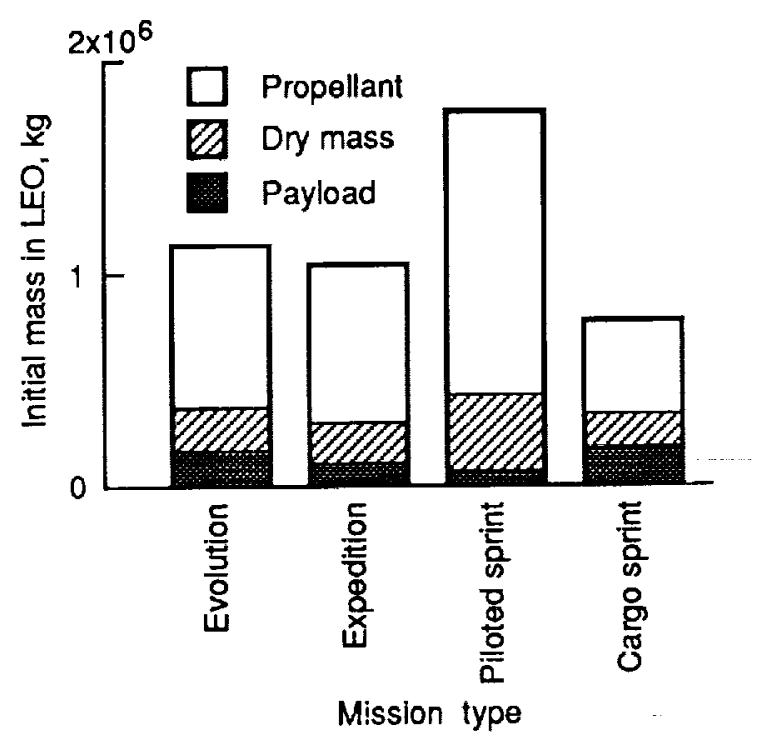

Figure 1.-Initial mass in low Earth orbit for various Mars missions.

density. Combusting metal in the exhaust increases the combustion temperature and hence the $I_{s p}$ of the propulsion system.

Table I contrasts the performance of several propulsion systems with and without metallized fuel. Using metallized propellant $\left(\mathrm{O}_{2} / \mathrm{H}_{2} / \mathrm{Al}\right)$ increases $I_{s p}$ by $5.9 \mathrm{lb}_{\mathrm{f}}-\mathrm{s} / \mathrm{lb}_{\mathrm{m}}$ over $\mathrm{O}_{2} / \mathrm{H}_{2}$ systems. The expansion ratio for the $\mathrm{O}_{2} / \mathrm{H}_{2}$ engines was 500:1. Also listed are the engine efficiencies $\eta$, the ratio of the actual delivered performance to the theoretical maximum performance.

The mixture ratios and metal loadings for these designs are provided in table II. The metal loading represents the fraction (by weight) of aluminum in the fuel. The mixture ratio is defined as it is for traditional chemical propulsion: the ratio of the total oxidizer mass to the total fuel mass.

The increases in propellant density lead to reductions in the tankage mass as well as in the overall propulsion system dry mass. Because many of the propulsion system elements are dependent on the propellant mass, the propellant density can have a large effect on the overall dry mass.

TABLE I.-ENGINE PERFORMANCE FOR INTERPLANETARY TRANSFER PROPULSION [Expansion ratio, 500:1.]

\begin{tabular}{|l|c|c|c|}
\hline Propellant & \multicolumn{2}{|c|}{$\begin{array}{c}\text { Specific impulse, } \\
I_{s p}, \\
\end{array}$} & \multicolumn{2}{|c|}{$\begin{array}{c}I_{s p} \\
\text { efficiency, } \\
\eta\end{array}$} \\
\cline { 2 - 3 } & No metal & $\begin{array}{c}\text { Metallized, } \\
\text { aluminum }\end{array}$ & \\
\hline NTO/MMH & 341.2 & 366.4 & 0.938 \\
$\mathrm{O}_{2} / \mathrm{MMH}_{\mathrm{m}}$ & 381.9 & 386.2 & .940 \\
$\mathrm{O}_{2} / \mathrm{CH}_{4}$ & 382.1 & 384.3 & .940 \\
$\mathrm{O}_{2} / \mathrm{H}_{2}$ & 479.5 & 485.4 & .984 \\
\hline
\end{tabular}

TABLE II.-ENGINE DESIGN PARAMETERS

\begin{tabular}{|l|c|c|}
\hline \multirow{2}{*}{ Propellant } & \multicolumn{2}{|c|}{ Mixture ratio } \\
\cline { 2 - 3 } & No metal & $\begin{array}{c}\text { Metallized } \\
\text { (aluminum loading) }\end{array}$ \\
\cline { 2 - 3 } & & $0.9(50)$ \\
$\mathrm{NTO} / \mathrm{MMH}$ & 2.0 & $.9(35)$ \\
$\mathrm{O}_{2} / \mathrm{MMH}$ & 1.7 & $1.8(45)$ \\
$\mathrm{O}_{2} / \mathrm{CH}_{4}$ & 3.7 & $1.6(60)$ \\
$\mathrm{O}_{2} / \mathrm{H}_{2}$ & 6.0 & \\
\hline
\end{tabular}

In order to determine the benefits of using metallized propellants for Mars missions, the mission and propulsion system designs must be considered together and analyzed. The succeeding sections discuss these designs and the results of the overall systems analysis.

\section{Human Missions to Mars}

Several types of Mars missions have been considered in the current NASA studies-most recently, the evolution and expedition missions (ref. 1). In the evolution mission the crew and the cargo are both sent to Mars on the same vehicle. The round-trip flight times (not including the time on the surface) for these missions are 700 to 800 days. The departure from Earth to Mars requires a lower energy than the sprint missions (a 400-day trip).

The expedition mission is similar to the evolution mission. The primary difference is the orbit of the orbiting vehicle. The expedition Mars excursion vehicle (MEv) descends from and returns to a vehicle orbiting at $500-$ by $582-\mathrm{km}$ altitude and $50^{\circ}$ inclination. The evolution mission orbits are either around Phobos $\left(6030-\mathrm{km}\right.$ altitude, $2^{\circ}$ inclination) or highly elliptical and highly inclined $\left(250-\right.$ by $18000-\mathrm{km}$ altitude, $28^{\circ}$ inclination; or 250 - by $33120-\mathrm{km}$ altitude, $0^{\circ}$ inclination). These orbits require a larger MEV than does the expedition mission.

Earlier studies had proposed the sprint mission (refs. 3 and 4 and personal communication from A. Friedlander). This mission scenario separates the piloted crew elements from the unmanned cargo elements that are not required until the crew arrives at Mars (the excursion vehicle, science instruments, and the propellant and tankage to return the crew to Earth). The heavy cargo elements are delivered to Mars on a lowenergy trajectory. The sprint missions have been given less emphasis because of the large LEO masses required. Also, the separation of the crew from its ability to return to Earth (its return propellant) is currently considered a great mission risk.

\section{Mission Analysis}

In estimating the vehicle masses the maneuvers are described by a series of velocity changes $\Delta V \mathrm{~s}$. The $\Delta V$ is computed as follows: 
TABLE III.-MISSION VELOCITY CHANGES

[From reference 1.]

(a) Evolution and expedition missions

\begin{tabular}{|l|r|r|}
\hline \multicolumn{1}{|c|}{ Maneuver } & $\begin{array}{c}\text { Evolution } \\
\text { mission }\end{array}$ & $\begin{array}{c}\text { Expedition } \\
\text { mission }\end{array}$ \\
\cline { 2 - 3 } & \multicolumn{2}{|c|}{ Velocity change, $\Delta V, \mathrm{~km} / \mathrm{s}$} \\
\hline Preinjection preparation & 100 & 10 \\
Trans-Mars injection & 4300 & 4400 \\
Trans-Mars coast & 50 & 50 \\
Mars orbit insertion & 20 & 100 \\
Mars orbit operations & 50 & 20 \\
Trans-Earth injection & 2650 & 3900 \\
Trans-Earth coast & 50 & 50 \\
Earth orbit insertion & 40 & $(\mathrm{a})$ \\
Earth orbit operations & 200 & $(\mathrm{a})$ \\
Excursion: & 10 & 10 \\
Pre-deorbit preparation & 1400 & 600 \\
Deorbit to landing & 5800 & 4200 \\
Ascent &
\end{tabular}

(b) High-energy split sprint mission (personal communication with A. Friedlander)

\begin{tabular}{|c|c|}
\hline Maneuver & $\begin{array}{l}\text { Velocity } \\
\text { change, } \\
\Delta V \text {, } \\
\mathrm{km} / \mathrm{s}\end{array}$ \\
\hline $\begin{array}{l}\text { Piloted mission: } \\
\text { Preinjection preparation } \\
\text { Trans-Mars injection } \\
\text { Trans-Mars coast } \\
\text { Mars orbit insertion } \\
\text { Mars orbit operations } \\
\text { Trans-Earth injection } \\
\text { Trans-Earth coast } \\
\text { Earth orbit insertion } \\
\text { Earth orbit operations } \\
\text { Cargo mission: } \\
\text { Preinjection preparation } \\
\text { Trans-Mars injection } \\
\text { Trans-Mars coast } \\
\text { Mars orbit insertion } \\
\text { Mars orbit operations } \\
\text { Excursion: } \\
\text { Pre-deorbit preparation } \\
\text { Deorbit to landing } \\
\text { Ascent to orbit }\end{array}$ & $\begin{array}{r}0 \\
\mathrm{~b} 7780 \\
50 \\
0 \\
207 \\
3148 \\
50 \\
0 \\
121 \\
\\
0 \\
\mathrm{c} 3556 \\
50 \\
0 \\
207 \\
\\
0 \\
1100 \\
4500\end{array}$ \\
\hline $\begin{array}{l}\text { a Not applicable. } \\
\text { b Three stages are used for departure } \\
\text { and second stages are reused. The } \\
0.032+0.121=0.153 \mathrm{~km} / \mathrm{s} \text { for } \\
\text { and } 2.59+0.032+0.121=2.7 \\
\text { second stage. }\end{array}$ & $\begin{array}{l}\text { the first } \\
\text { firn } \Delta V \text { is } \\
\text { first stage } \\
m / s \text { for the }\end{array}$ \\
\hline
\end{tabular}

$$
\Delta V=I_{s p} g \ln \left(\frac{m_{0}}{m_{f}}\right)
$$

where

$$
\begin{array}{ll}
\Delta V & \text { velocity change, } \mathrm{m} / \mathrm{s} \\
I_{s p} & \text { specific impulse, } \mathrm{lb}_{\mathrm{f}}-\mathrm{s} / \mathrm{lb}_{\mathrm{m}} \\
g & \text { gravitational acceleration, } 9.81 \mathrm{~m} / \mathrm{s} \\
m_{0} & \text { initial mass, } \mathrm{kg} \\
m_{f} & \text { final mass, } \mathrm{kg}
\end{array}
$$

The $\Delta V$ s for the Mars missions were taken from reference 1 and a personal communication with A. Friedlander. Table III lists the $\Delta V$ s for the different types of missions analyzed. In table III(b) the $\Delta V$ s for similar-energy maneuvers (Earth and Mars orbit insertions) do not correspond exactly to those shown in table III(a). They were produced before the Office of Exploration had developed their current standard set of Mars mission assumptions. The differences between the cases, however, are small. Table IV provides the payload masses for the three types of Mars missions. Note that a large propellant load for the Earth return is the major payload on the sprint cargo vehicle.

\section{Evolution and Expedition Missions}

In the evolution and expedition missions, all of the mission elements are on one vehicle: crew, excursion vehicle, Earth return propellant, and crew modules. Aerobraking is used for the Mars orbit insertion and the Earth orbit insertion maneuvers. The trans-Mars injection is performed with a single stage. This stage is expended and not returned to Earth. Before Mars orbit insertion the excursion vehicle is separated from the main crew module. Because each vehicle enters Mars orbit separately, the aerobrake on each is smaller than one

\begin{tabular}{|c|c|c|c|}
\hline & \multicolumn{3}{|c|}{ Types of mission } \\
\hline & Evolution & Expedition & Split sprint \\
\hline & \multicolumn{3}{|c|}{ Mass, kg } \\
\hline $\begin{array}{l}\text { Crew modules and } \\
\text { consumables }\end{array}$ & 46192 & 46192 & b80 717 \\
\hline Mars excursion $\left(\mathrm{O}_{2} / \mathrm{H}_{2}\right)$ & 124058 & 69448 & ${ }^{a} 60000$ \\
\hline $\begin{array}{l}\text { Return propellant } \\
\text { and tankage }\end{array}$ & ------- & $\cdots$ & a 120167 \\
\hline Science payload, etc. & ------ & ------- & 20000 \\
\hline Mass returned to LEO & 46192 & 7000 & b5 000 \\
\hline
\end{tabular}
designed to protect the entire payload. Also, the excursion vehicle's aerobrake is used twice: once for aerocapture at Mars and once for the descent to the surface. In the evolution mission

TABLE IV. - MISSION PAYLOAD MASSES

[From references 1 and 4 and personal communicaton with $B$. Donahue.] 
both the crew and its module return to LEo. In the expedition mission the crew module is expended prior to Earth orbit insertion and the crew proceeds to LEO in a small capsule.

\section{Sprint Missions}

In the split sprint mission the crew and their return propellant are on separate vehicles: a piloted vehicle and a cargo vehicle. The piloted vehicle uses three stages for the trans-Mars injection. Aerobraking is used to return the first two stages to LEo for reuse. The third stage remains with the piloted vehicle and is later used for the trans-Earth injection.

The cargo vehicle's trans-Mars injection is performed with one stage. Again aerobraking is used to return the stage to LEO. The cargo vehicle carries the excursion vehicle, the mission science payload, and the propellant to return the astronauts to Earth. After performing their mission the astronauts return to either the space station or Earth's surface in a small capsule, the module that sustained them during the Mars-Earth transfer having been expended prior to Earth orbit insertion.

The reusability of the sprint mission stages requires several maneuvers to return them to LEO. The piloted vehicle has its trans-Mars injection $\Delta V$ broken into three parts: $2.59 \mathrm{~km} / \mathrm{s}$ delivered by the first stage, the same $\Delta V$ by the second stage, and $2.60 \mathrm{~km} / \mathrm{s}$ by the third stage. The total $\Delta V$ is $7.78 \mathrm{~km} / \mathrm{s}$. The first stage performs two small maneuvers to return to LEO with a total $\Delta V$ of $0.153 \mathrm{~km} / \mathrm{s}$. Because the second stage is on an Earth-escape trajectory when it separates from the piloted vehicle, it must return to the Earth's gravitational influence before it can aerobrake into LEO. Therefore, it delivers an additional $2.59-\mathrm{km} / \mathrm{s} \Delta V$ as well as the $0.153-\mathrm{km} / \mathrm{s} \Delta V$ for aerobraking. Once it has burned out, the cargo mission stage has also exceeded Earth's escape velocity. It must therefore perform an added $0.964-\mathrm{km} / \mathrm{s} \Delta V$ (as well as the $0.153-\mathrm{km} / \mathrm{s}$ $\Delta V$ for aerobraking) to return to LEO.

\section{Propulsion System Design}

\section{Engine Performance}

The engine performance of several metallized propellant combinations was estimated with a computer simulation code (ref. 8). An engine $I_{s p}$ efficiency was used to reduce the codepredicted $I_{s p}$. The efficiency is the ratio of the actual delivered performance to the theoretical maximum $I_{s p}$. This reduction reflected the losses incurred from the nozzle boundary layer, engine cycle inefficiencies, and other propulsion system losses. The engine efficiencies were derived by comparing the performance estimates from references 9 to 12 with the vacuum $I_{s p}$ predicted by the engine code.

Tables I and V provide the design $I_{s p}$ 's selected for the various Mars missions. The engine chamber pressure was $1000 \mathrm{psia}$ and the propellants were provided to the combustion chamber in the liquid state. Because packaging constraints may limit the size of the large-expansion-ratio nozzles, an expansion
TABLE V.-ENGINE PERFORMANCE FOR MARS EXCURSION PROPULSION

[Expansion ratio, 200:1.]

\begin{tabular}{|l|c|c|c|}
\hline Propellant & \multicolumn{2}{c|}{$\begin{array}{c}\text { Specific impulse, } \\
I_{s p}, \\
\mathrm{Ib}_{\mathrm{f}}-\mathrm{s} / \mathrm{lb}_{\mathrm{m}}\end{array}$} & $\begin{array}{c}I_{s p} \\
\text { efficiency, } \\
\end{array}$ \\
\cline { 2 - 3 } & No metal & $\begin{array}{r}\text { Metallized } \\
\text { (aluminum) }\end{array}$ & \\
\hline $\mathrm{NTO} / \mathrm{MMH}$ & 334.7 & 354.4 & 0.938 \\
$\mathrm{O}_{2} / \mathrm{MMH}$ & 371.5 & 374.4 & .940 \\
$\mathrm{O}_{2} / \mathrm{CH}_{4}$ & 371.4 & 372.2 & .940 \\
$\mathrm{O}_{2} / \mathrm{H}_{2}$ & 470.1 & 475.3 & .984 \\
\hline
\end{tabular}

ratio of 500:1 was selected for the transfer vehicle and 200:1 for the excursion vehicle. The $I_{s p}$ 's were $485.4 \mathrm{lb}_{\mathrm{f}}-\mathrm{s} / \mathrm{lb} \mathrm{b}_{\mathrm{m}}$ for the trans-Mars injection stage and the Mars transfer vehicle and $475.3 \mathrm{lb}_{\mathrm{f}}-\mathrm{s} / \mathrm{lb}_{\mathrm{m}}$ for the Mars excursion vehicle.

\section{Propellant Density}

When the aluminum loadings considered in the engine performance calculations are used, the $\mathrm{H}_{2}$ propellant density can increase from $70 \mathrm{~kg} / \mathrm{m}^{3}$ ( $\mathrm{H}_{2}$ with no aluminum loading) to $169 \mathrm{~kg} / \mathrm{m}^{3}\left(\mathrm{H}_{2}\right.$ with a 60 -percent aluminum loading). The density increase is computed by the following equation:

$$
\rho_{p, m}=\frac{\frac{\mathrm{ML}}{1-\mathrm{ML}}+1}{\frac{\mathrm{ML}}{(1-\mathrm{ML}) \rho_{m}}+\frac{1}{\rho_{p}}}
$$

where

$\rho_{p, m}$ density of metallized oxidizer or fuel, $\mathrm{kg} / \mathrm{m}^{3}$

ML metal loading (fraction of fuel mass)

$\rho_{m} \quad$ density of metal in oxidizer or fuel, $\mathrm{kg} / \mathrm{m}^{3}$

$\rho_{p}$ density of nonmetallized oxidizer or fuel, $\mathrm{kg} / \mathrm{m}^{3}$

\section{Selection of Best Density- $I_{s p}$ Design Points}

Tradeoff studies must be conducted to determine the "best" $I_{s p}$ and propellant density for each propulsion system so that the maximal reduction in LEo mass or the maximal payload increase can be achieved. Figure 2 shows the results of one of these tradeoff studies on $I_{s p}$. The maximal metal loading considered was 60 percent of the fuel mass. A higher $I_{s p}$ is produced at higher metal loadings. The selection of the 60-percent loading performance level was determined by the metal loading experience with solid rocket motors. The total metal loading of all of the propellant (oxidizer and fuel) was 23 percent. This loading is comparable to that of solid propulsion systems. Although a higher $I_{s p}$ is predicted for 


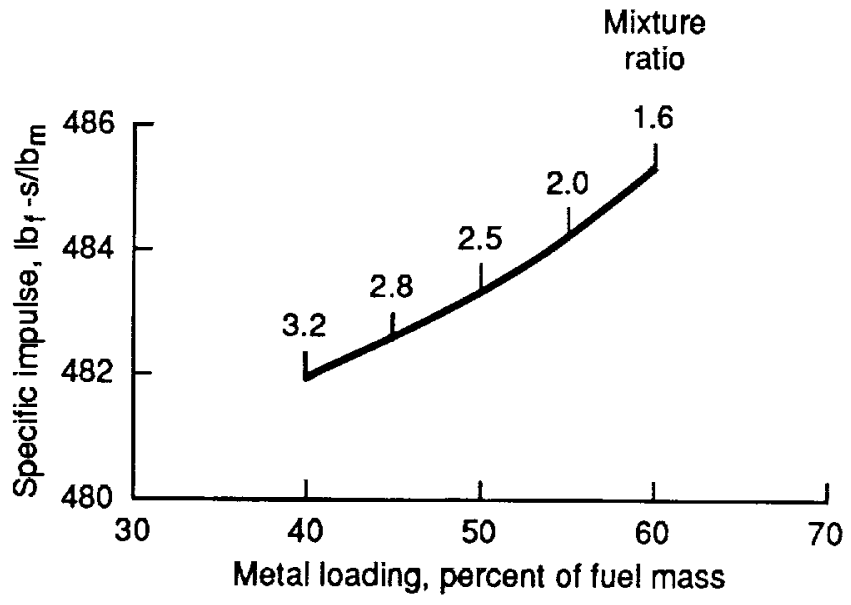

Figure 2.-Specific impulse as a function of metal loading. Expansion ratio, 500:1

higher metal content, the 60 -percent loading was chosen to stay within the experience level gained with solid propulsion systems. An $I_{s p}$ of $485.4 \mathrm{Ib}_{\mathrm{f}}-\mathrm{s} / \mathrm{lb}_{\mathrm{m}}$ was delivered at a metal loading of 60 percent of the $\mathrm{H}_{2} / \mathrm{Al}$, an expansion ratio of $500: 1$, and a mixture ratio of 1.6. The effect of metal loading on the propulsion system dry mass and its influence on the selection of the $I_{s p}$ design point are discussed later in this report.

\section{Mass-Scaling Equations}

In determining the dry mass of the Mars vehicles the following general mass-scaling equation was used:

$$
m_{\mathrm{dry}}=A+B m_{p}+C m_{p}^{2 / 3}+D m_{\mathrm{entry}}
$$

$$
\begin{array}{ll}
A, B, C, D & \text { mass-scaling parameters (provided in table } \mathrm{VI} \text { ) } \\
m_{p} & \text { propellant mass, } \mathrm{kg} \\
m_{\mathrm{ennry}} & \text { total entry mass during aerobraking maneuver, } \mathrm{kg}
\end{array}
$$

\begin{tabular}{|c|c|c|c|c|}
\hline \multirow[t]{2}{*}{ Propellants } & \multicolumn{4}{|c|}{ Scaling parameter } \\
\hline & $A$ & $B$ & $C$ & $D$ \\
\hline \multicolumn{5}{|c|}{ Trans-Mars injection stage and Mars transfer vehicle } \\
\hline $\begin{array}{l}\mathrm{O}_{2} / \mathrm{H}_{2} \\
\mathrm{O}_{2} / \mathrm{H}_{2} / \mathrm{AI}\end{array}$ & $\begin{array}{l}1363.51 \\
1363.51\end{array}$ & $\begin{array}{r}0.1668 \\
.1669\end{array}$ & $\begin{array}{r}0.0799 \\
.0786\end{array}$ & $\begin{array}{r}0.15 \\
.15\end{array}$ \\
\hline \multicolumn{5}{|c|}{ Mars excursion vehicle } \\
\hline $\begin{array}{l}\mathrm{NTO} / \mathrm{MMH} / \mathrm{Al} \\
\mathrm{O}_{2} / \mathrm{MMH} / \mathrm{Al} \\
\mathrm{O}_{2} / \mathrm{CH}_{4} / \mathrm{Al} \\
\mathrm{O}_{2} / \mathrm{H}_{2} \\
\mathrm{O}_{2} / \mathrm{H}_{2} / \mathrm{Al}\end{array}$ & 1363.51 & $\begin{array}{r}0.1484 \\
.1504 \\
.1580 \\
.1811 \\
.1812\end{array}$ & $\begin{array}{r}0.0000 \\
.0183 \\
.0439 \\
.0806 \\
.0793\end{array}$ & 0.15 \\
\hline
\end{tabular}

TABLE VI.--PROPULSION SYSTEM MASS-SCALING PARAMETERS FOR VARIOUS PROPELLANTS
TABLE VII.-PROPULSION SYSTEM MASSSCALING PARAMETERS FOR THREE METAL LOADINGS

[Propellant, $\mathrm{O}_{2} / \mathrm{H}_{2} / \mathrm{Al}$; trans-Mars injection stage and Mars transfer vehicle propulsion systems.]

\begin{tabular}{|c|c|c|r|r|}
\hline \multirow{2}{*}{$\begin{array}{r}\text { Metal } \\
\text { loading, } \\
\text { percent }\end{array}$} & \multicolumn{4}{|c|}{ Scaling parameter } \\
\cline { 3 - 5 } & $A$ & $B$ & \multicolumn{1}{|c|}{$C$} & $D$ \\
\hline 40 & 1363.51 & 0.1661 & 0.0785 & 0.15 \\
50 & 1363.51 & .1656 & .0777 & .15 \\
60 & 1363.51 & .1669 & .0786 & .15 \\
\hline
\end{tabular}

Table VII provides the propulsion system mass-scaling parameters for the metallized systems. These parameters model all of the masses required to store and provide propellants to the main engines. They include tankage, engines, feed system, thermal control, structure, residuals, and contingency. The scaling parameter $A$ varied from 349 to 1364 for the Mars vehicles. The variation is due to the differing feed system configurations and number of engines for each stage. Only the latter value of $A$ is shown in the table. The specific mixture ratios and the metal loadings are listed in table II. All of the propellant combinations other than $\mathrm{O}_{2} / \mathrm{H}_{2}$ were used only for the Mars excursion vehicle ascent stage.

The propellant tankage for all of the systems has a 50-psia maximal operating pressure. The propellant is stored at 30 psia. All of the tankage for $\mathrm{O}_{2}, \mathrm{H}_{2}$, and methane $\left(\mathrm{CH}_{4}\right)$ is composed of aluminum alloy. The tanks for nitrogen tetroxide (NTO) and monomethyl hydrazine (MMH) are made of titanium. The flange factor and the safety factor for the propellant tanks are 1.4 and 2.0 , respectively. The safety factor is based on the tank material's ultimate stress. The propellant residual and holdup factor for the transfer vehicle equation is 1.5 percent of the total propellant mass. This factor is 2.7 percent for the smaller excursion vehicle tankage.

Each space-storable and cryogenic propulsion system uses autogenous pressurization. Only the NTO/MMH system uses regulated pressurization. The pressurant is helium. The maximal operating pressure in the pressurant tank is 3722 psia. The storage pressure is 3444 psia. The flange factor and the safety factor for the pressurant tanks are 1.1 and 2.0, respectively. A small helium pressurization system is provided for the autogenous systems. It can pressurize one-tenth of the total propellant tank volume.

For thermal control the cryogenic propellants $\mathrm{CO}_{2}, \mathrm{H}_{2}$, and $\mathrm{CH}_{4}$ ) have a high-performance multilayer insulation and a thin-wall vacuum jacket. The jacket is sized for a 30 -psia maximal operating pressure. After the vehicle reaches space, it is vented and evacuated. The storable propellants only require a lower-performance multilayer insulation.

The aerobrake mass is 15 percent of the vehicle mass entering the atmosphere. This mass includes the payload, the propulsion system dry mass, any needed propellant for the post-entry circularization firing, and the aerobrake. 
As discussed previously, the metal loading may have an important effect on the propulsion system dry mass. The maximum- $I_{s p}$ design point, however, may require a heavier propulsion system than the nonmetalized propellant design case. Table VII compares the propulsion system mass-scaling parameters for three metal loadings. There is a small variation in the total mass of the propulsion system with the different metal loadings. On the basis of the tradeoff studies the highest- $I_{s p}$ system (which has a metal loading of 60 percent) was selected.

\section{Design and Sizing of Mars Excursion Vehicle}

The excursion vehicle is sized to deliver the $\Delta V$ s listed in table III. In the baseline evolution and expedition mission scenarios, the payloads delivered to the Mars surface have a total mass of $25000 \mathrm{~kg}$ per flight. An additional $4000-\mathrm{kg}$ module carries the crew during the landing mission and is returned to Mars orbit. In the sprint mission scenario, only $12400 \mathrm{~kg}$ is delivered to the surface. As in the other missions a $4000-\mathrm{kg}$ module is returned to Mars orbit.

During the descent the same aeroshell is used for the aerocapture maneuver for Mars orbit insertion and the atmospheric entry at Mars. The aeroshell is separated from the excursion vehicle before the final landing, but not until all but $0.3 \mathrm{~km} / \mathrm{s}$ of the descent $\Delta V$ has been delivered. This reduces both the total mass of the excursion vehicle and the total propellant mass required for landing. The aeroshell is 15 percent of the initial excursion vehicle aerocapture mass. For the Mars evolution mission using $\mathrm{O}_{2} / \mathrm{H}_{2}$ this mass is $18600 \mathrm{~kg}$. For the ascent stage the parameters in table VI are used but without the aerobrake mass. Another important aspect of the excursion vehicle is its leg structure to support it on Mars. It is part of the descent stage and the leg mäss is 2 percent of the total mass landed on the surface.

The mass-scaling equation for the excursion vehicle stages is

$$
m_{\mathrm{dry}}=A+B m_{p}+C m_{p}^{2 / 3}+D m_{\mathrm{entry}}+E m_{\text {landed }}
$$

where

$$
\begin{array}{ll}
E & \text { mass parameter for leg structure, } 0.02 \\
m_{\text {landed }} & \text { total landed mass on surface, } \mathrm{kg}
\end{array}
$$

No aerobrake or leg structure is used for the ascent stage.

\section{Results}

Several mass sensitivity studies are discussed in this section. They include the added payload that can be delivered to Mars (given a constant initial LEO mass), the LEO mass reductions afforded by cryogenic metallized propellants, and the potential effect of using storable metallized propellants for the Mars ascent.

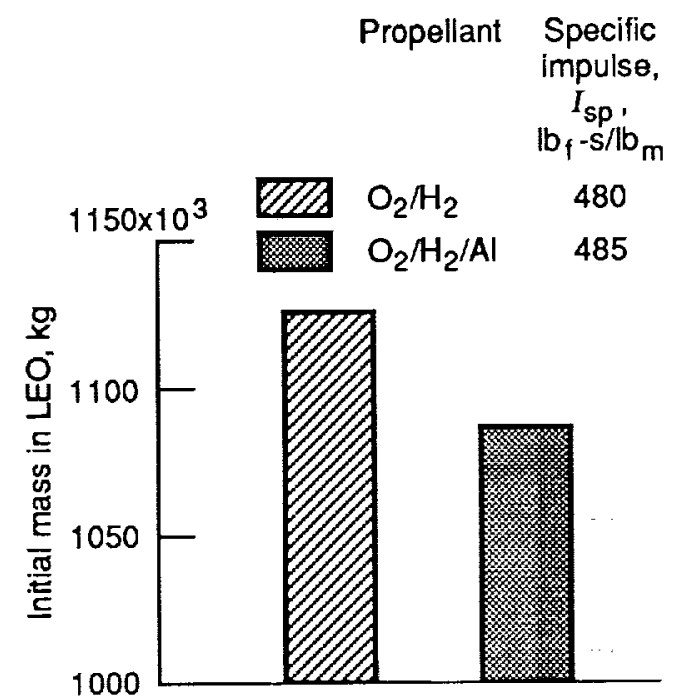

Figure 3. - Initial mass in low Earth orbit saved when metallized propellants are used for all propulsion systems-evolution mission.

\section{LEO Mass Reduction for Trans-Mars Injection Stage}

Figure 3 shows the LEo mass saving for the Mars evolution mission vehicle when metallized propellants are used. If they are used for all of the mission maneuvers, the LEO mass is reduced by 3.3 percent. Using the increased $I_{s p}$ of metallized propulsion to reduce the LEo mass on a per-vehicle basis does not produce a significant saving. As discussed later, the most significant mass advantage is gained by increasing the payload delivered to Mars.

\section{Payload Mass Sensitivity of Mars Excursion Vehicle to Constant LEO Departure Mass}

The most significant benefit of metallized propellants is their ability to deliver added payload to Mars. Figure 4(a) contrasts the payload delivery capabilities of $\mathrm{O}_{2} / \mathrm{H}_{2}$ and metallized propulsion for the Mars expedition mission. Using metallized $\mathrm{O}_{2} / \mathrm{H}_{2} / \mathrm{Al}$ increases the payload to the surface of Mars by 22 percent for the expedition mission. The initial masses in LEO for the two types of vehicles (metallized and nonmetallized propellant) are equal. However, the mass saving (in the excursion vehicle ascent stage, the Mars transfer vehicle, and the trans-Mars injection stage) by using the higher- $I_{s p}$ metallized propellants is placed into the excursion vehicle's mass. Hence, the metallized excursion vehicle has a higher initial mass and is able to place 20 to 22 percent more payload on Mars.

A similar benefit is possible with the split sprint mission. The payload increase to the Mars surface (shown in fig. 4(b)) is 33 percent (16 $500 \mathrm{~kg}$ with metallized propellants versus $12400 \mathrm{~kg}$ ). The potential benefits of added payload are longer stay time on the surface, more flexibility to land large, massive payload on the surface, and the ability to land added science payload on the surface. 


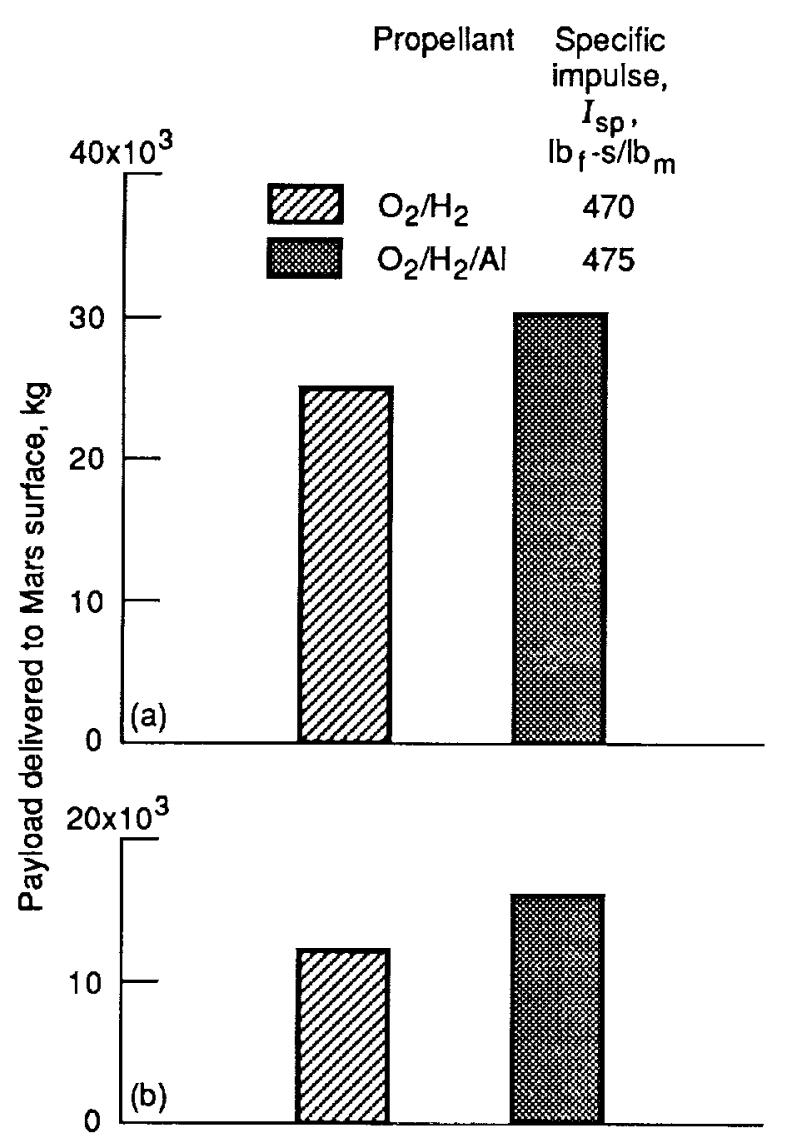

(a) Expedition mission

(b) Split sprint mission.

Figure 4.-Increase in Mars excursion vehicle payload with metallized propellants-expedition mission.

The evolution and expedition excursion vehicle masses are summarized in table VIII. The descent payload increases from 25000 to $30000 \mathrm{~kg}$ for the evolution mission and to $30500 \mathrm{~kg}$ for the expedition mission when metallized fuels are used. The descent stage propellant mass to land the added payload increases by $1600 \mathrm{~kg}$ for the evolution mission and by $980 \mathrm{~kg}$ for the expedition mission.

\section{Reduced Launch Requirements}

Figure 5 compares the total mass delivered to Mars using $\mathrm{O}_{2} / \mathrm{H}_{2}$ and $\mathrm{O}_{2} / \mathrm{H}_{2} / \mathrm{Al}$. With the increases in delivered payload the total number of launches required is reduced significantly. For a large Mars base construction or extensive exploration program the 20-percent payload increase translates into 16 fewer STs-C launches ( 80 versus 96) for a total of $150000 \mathrm{~kg}$ of payload delivered to the Mars surface. For the evolution mission, a minimum of $16 \mathrm{sTs}-\mathrm{C}$ launches $(68000 \mathrm{~kg}$ per flight) would be required to deliver the $1052000-\mathrm{kg}$ vehicle mass to LEo (table IX). Similarly, 17 sTs-c launches would be saved when using expedition vehicles (or a $1124000-\mathrm{kg}$ initial LEO mass). With metallized propellants only five Mars
TABLE VIII.-MARS EXCURSION VEHICLE MASSES FOR ASCENT AND DESCENT STAGES WTTH $\mathrm{O}_{2} / \mathrm{H}_{2}$ AND $\mathrm{O}_{2} / \mathrm{H}_{2} / \mathrm{Al}$ PROPELLANTS

\begin{tabular}{|c|c|c|c|c|}
\hline \multirow[t]{3}{*}{ Element } & \multicolumn{2}{|c|}{ Evolution mission } & \multicolumn{2}{|c|}{ Expedition mission } \\
\hline & $\mathrm{O}_{2} / \mathrm{H}_{2}$ & $\mathrm{O}_{2} / \mathrm{H}_{2} / \mathrm{Al}$ & $\mathrm{O}_{2} / \mathrm{H}_{2}$ & $\mathrm{O}_{2} / \mathrm{H}_{2} / \mathrm{Al}$ \\
\hline & \multicolumn{4}{|c|}{ Mass, kg } \\
\hline \multicolumn{5}{|c|}{ Ascent stage } \\
\hline Ascent payload & 4000 & 4000 & 4000 & 4000 \\
\hline $\begin{array}{l}\text { Adapter (second stage } \\
\text { and payload) }\end{array}$ & 211 & 211 & 211 & 211 \\
\hline Propellant tankage & 514 & 491 & 225 & 218 \\
\hline Pressurization & 110 & 115 & 48 & $5 !$ \\
\hline Engines and feed system & 1240 & 1240 & 1240 & 1240 \\
\hline Thermal control & 1187 & 1144 & 527 & 514 \\
\hline Structure & 1828 & 1764 & 799 & 781 \\
\hline Residuals and holdup & 725 & 699 & 317 & 310 \\
\hline Contingency (10 percent) & 560 & 545 & 316 & 311 \\
\hline Usable propellant & 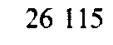 & 25207 & 11418 & 11159 \\
\hline \multicolumn{5}{|c|}{ Descent stage } \\
\hline Descent payload & 25000 & 30000 & 25000 & 30500 \\
\hline $\begin{array}{l}\text { Adapter (first and } \\
\text { second stages) }\end{array}$ & 3236 & 3443 & 2321 & 2594 \\
\hline Propellant tankage & 647 & 672 & 187 & 205 \\
\hline Pressurization & 138 & 158 & 40 & 48 \\
\hline Engines and feed system & 317 & 317 & 317 & 317 \\
\hline Thermal control & 1489 & 1554 & 442 & 484 \\
\hline Structure & 2302 & 2412 & 666 & 734 \\
\hline Residuals and holdup & 913 & 956 & 264 & 291 \\
\hline Contingency (10 percent) & 581 & 607. & 192 & 208 \\
\hline Leg structure & I 451 & 1542 & 990 & 1106 \\
\hline Aeroshell & 18609 & 19683 & 10417 & 11607 \\
\hline Usable propellant & 32885 & 34462 & 9511 & 10491 \\
\hline Total ${ }^{\mathbf{a}}$ & 124058 & 131222 & 69448 & 77380 \\
\hline
\end{tabular}

${ }^{a}$ The total masses differ because for a constant mass in LEO the metallized propulsion option will allow a larger mass to be delivered to Mars orbit and the excursion vehicle is able to deliver more payload to the Martian surface.

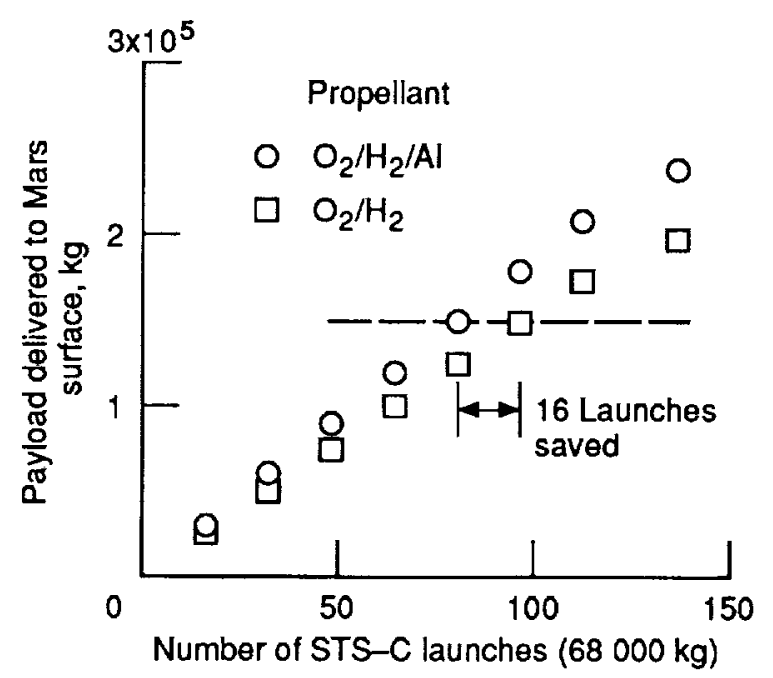

Figure 5.-Mars surface payload as a function of number of STS-C launches-evolution mission. 
TABLE IX.-MARS-EXCURSION-VEHICLE AND LOW-EARTHORBIT MASSES WITH EARTH- AND SPACE-STORABLE (METALLIZED) PROPELLANTS FOR ASCENT PROPULSION

\begin{tabular}{|c|c|c|c|c|}
\hline \multirow[t]{3}{*}{ Propellant } & \multicolumn{2}{|c|}{ Mars excursion vehicle } & \multicolumn{2}{|c|}{ Low Earth orbit } \\
\hline & $\begin{array}{c}\text { Evolution } \\
\text { míssion }\end{array}$ & $\begin{array}{l}\text { Expedition } \\
\text { mission }\end{array}$ & $\begin{array}{c}\text { Evolution } \\
\text { mission }\end{array}$ & $\begin{array}{c}\text { Expedition } \\
\text { mission }\end{array}$ \\
\hline & \multicolumn{4}{|c|}{ Mass, kg } \\
\hline \multicolumn{5}{|c|}{ Expansion ratio for metallized propellants, $200: 1$} \\
\hline $\mathrm{O}_{2} / \mathrm{H}_{2}$ & 124058 & 69448 & 1124000 & 1052000 \\
\hline $\mathrm{NTO} / \mathrm{MMH} / \mathrm{Al}$ & 214898 & 84333 & 1478800 & 1108400 \\
\hline $\mathrm{O}_{2} / \mathrm{MMH} / \mathrm{Al}$ & 180321 & 79972 & 1344000 & 1091300 \\
\hline $\mathrm{O}_{2} / \mathrm{CH}_{4} / \mathrm{Al}$ & 194946 & 81952 & 1401000 & 1099000 \\
\hline \multicolumn{5}{|c|}{ Expansion ratio for metallized propellants, $500: 1$. } \\
\hline $\mathrm{O}_{2} / \mathrm{H}_{2}$ & 124058 & 69448 & 1124000 & 1052000 \\
\hline NTO/MMH/Al & 190063 & 81363 & 1382000 & 1096000 \\
\hline $\mathrm{O}_{2} / \mathrm{MMH} / \mathrm{Al}$ & 164865 & 77763 & 1283700 & 1082600 \\
\hline $\mathrm{O}_{2} / \mathrm{CH}_{4} / \mathrm{AI}$ & 175521 & 79025 & 1325300 & 1087600 \\
\hline
\end{tabular}

evolution vehicles would be needed (each delivering $30000 \mathrm{~kg}$ ). With conventional $\mathrm{O}_{2} / \mathrm{H}_{2}$ six such vehicles would be needed.

The schedule savings and cost savings of reduced launch requirernents can be significant. Sixteen launches to LEO are required for each Mars vehicle. A maximum of six launches per year may be achieved with either the STS-C or the advanced launch system (ALS) (refs. 1, 4, and 13). This translates into an average rate of one launch every 2 months. Thus, for 16 launches, 32 months (or 2.7 years) are needed for the assembly of each Mars vehicle in LEO. Using metallized propellants reduces the time needed for assembling these elements of a $150000-\mathrm{kg}$ Mars base by 2.7 years (one fewer vehicle required). The reduction in launch vehicle procurement costs and the reduction in launch operations associated with fewer launches is, of course, also a major cost saving.

\section{Storable Propellant Options}

Another possible advantage of metallized propellants may be the use of advanced Earth- or space-storable propellants for the Mars ascent (ref. 7 and personal communication with B. Donahue). Because the time on the Mars surface may be long (20 to more than 600 days), a cryogenic propulsion system may have an extremely high propellant boiloff mass. Therefore, other alternatives to using hydrogen as a fuel for a planetary excursion vehicle are being considered. Metallized propellant combinations using oxygen/methane, oxygen/ monomethyl hydrazine, or nitrogen tetroxide/monomethyl hydrazine are possible alternatives. These storable, or "soft," cryogenic propellants can lower the propellant boiloff rate and potentially simplify the excursion vehicle's thermal design.

Tables IX compares the masses of excursion vehicles using non- $\mathrm{O}_{2} / \mathrm{H}_{2}$ ascent propulsion for expansion ratios of $200: 1$ and 500:1. Each lander delivers the baseline $25000 \mathrm{~kg}$ to the Mars surface. The MEv mass penalty for using this type of propulsion is relatively small for the expedition vehicles: 8000 to $14000 \mathrm{~kg}$ over those using $\mathrm{O}_{2} / \mathrm{H}_{2}$. This is not true for evolution vehicle cases. The mass penalties for the evolution cases are much larger and range from 40000 to $90000 \mathrm{~kg}$. Also in the tables the corresponding LEo initial masses for the different excursion vehicle options are provided. Again, for the expedition mission the LEO mass penalties are small: 30000 to $56000 \mathrm{~kg}$, or 2.9 to 5.3 percent. Thus, only a small LEO mass penalty must be paid to benefit from simplifying the storage of cryogenic propellants by using only a "soft" $\left(90 \mathrm{~K} \mathrm{O}_{2}\right)$ cryogen versus a $20 \mathrm{~K}$ propellant $\left(\mathrm{H}_{2}\right)$.

\section{System Design Issues}

\section{Engine Efficiency}

Engine efficiency is critical to achieving the performance advantages of metallized propellants. Without the predicted increases in $I_{s p}$ the advantages of these propellants are significantly reduced. Numerical modeling, propellant rheology experiments, and hot-fire engine testing are under way to determine potential engine efficiency with metallized propellants (refs. 14 to 17). All these areas of research are focused on applying metallized propellants to launch vehicles, upper stages, and planetary missions.

\section{Tank Configurations}

If the benefits of reduced LEO mass or increased payload are not desired or significant, increased propellant density can still benefit the Mars misssions. Because of the increased density the propellant tank size can be reduced, potentially offering better and smaller tank configurations. Also, the on-orbit assembly of the Mars vehicle may be easier with smaller tankage. Less MEV propellant tank volume is required for $\mathrm{O}_{2} / \mathrm{MMH} / \mathrm{Al}$ than for $\mathrm{O}_{2} / \mathrm{MMH}\left(16.7 \mathrm{~m}^{3}\right.$ versus $\left.18.66 \mathrm{~m}^{3}\right)$. This volume is also substantially smaller than that required for the $\mathrm{O}_{2} / \mathrm{H}_{2}\left(34.66 \mathrm{~m}^{3}\right)$.

Although, in the $\mathrm{O}_{2} / \mathrm{MMH} / \mathrm{Al}$ case, the tankage volume decreased, other applications will show a propellant volume increase. As an example, in the expedition mission the total $\mathrm{O}_{2}$ tank volume for the trans-Mars injection can be reduced from $509 \mathrm{~m}^{3}\left(\mathrm{O}_{2} / \mathrm{H}_{2}\right)$ to $366 \mathrm{~m}^{3}$ with metallized propellants $\left(\mathrm{O}_{2} / \mathrm{H}_{2} / \mathrm{Al}\right)$. The $\mathrm{H}_{2}$ tank volume, however, increases from $1396 \mathrm{~m}^{3}$ to $1560 \mathrm{~m}^{3}$ with metallized propellants. Overall, the total tank volume increases from $1905 \mathrm{~m}^{3}$ to $1926 \mathrm{~m}^{3}$ (a difference of only $21 \mathrm{~m}^{3}$, or 1.1 percent). This example is for the case where the Leo mass is held constant (at $1052000 \mathrm{~kg}$ ) for both the metallized and the nonmetallized $\mathrm{O}_{2} / \mathrm{H}_{2}$ systems using spherical tankage. Though the propellant tank volume increases, the higher $I_{s p}$ of metallized propellants allows 22 percent more payload to Mars. 


\section{Pump-Fed and Pressure-Fed Feed Systems}

The high-performance $\mathrm{O}_{2} / \mathrm{H}_{2}$ systems being considered for Mars exploration require a pump-fed engine, which typically needs less mass for propellant tankage and pressurization systems than pressure-fed propulsion systems. The propellant feed system must be designed to provide the non-Newtonian, thixotropic metallized propellant with the same reliability as the nonmetallized $\mathrm{H}_{2}$. Metallized propellants are currently fed to smaller propulsion systems with positive-displacement propellant expulsion devices such as diaphragms (ref. 18). These devices are also considered too impractical for large propellant tanks. For the extremely large propellant loads needed on the Mars missions, a different expulsion device will be required. The propellant flow properties are being studied both experimentally and analytically. These studies will help determine the best propellant acquisition and feed system for these large propulsion systems.

\section{Conclusions}

The primary advantage of metallized propellants for the NASA Mars missions is their ability to increase the surface payload delivery capability. With $\mathrm{O}_{2} / \mathrm{H}_{2} / \mathrm{Al}$ on the evolution and expedition missions the payload to the Mars surface is increased by 20 to 22 percent over $\mathrm{O}_{2} / \mathrm{H}_{2}$ propulsion. For sprint missions the payload mass increases can be up to 33 percent. With this added payload additional science experiments can be brought to the surface or more crew consumables can be delivered to Mars for a longer stay time on the planet.

This increase in payload also enables a faster delivery and assembly of the elements of a Mars base. With the 20-percent payload increase per mission, the number of STS-C launches needed to deliver $150000 \mathrm{~kg}$ to the surface can be reduced from 96 to 80 . This corresponds to reducing the number of Mars vehicles from 6 to 5 . This reduction in the number of Mars vehicles can significantly reduce the cost and schedule challenges.

With metallized propellants the initial mass in LEo can be modestly reduced. For the Mars evolution mission the initial mass in LEO can be reduced by 3.3 percent of the mass required with $\mathrm{O}_{2} / \mathrm{H}_{2}$ propulsion. This modest reduction does not significantly reduce the number of launches needed for each vehicle. The mass reductions enabled by metallized propellants are therefore more effective if they are translated into added payload delivered to Mars.

Earth- and space-storable propellants for the Mars ascent can provide an alternative to $\mathrm{O}_{2} / \mathrm{H}_{2}$ propulsion. The mostpromising candidate that allows the lowest storable propulsion mass for the ascent system is $\mathrm{O}_{2} / \mathrm{MMH} / \mathrm{Al}$. The LEO initial mass penalty for using metallized $\mathrm{O}_{2} / \mathrm{MMH} / \mathrm{Al}$ is only 3 to 5 percent over an all-cryogenic system for the expedition missions. These space-storable propellants have lower propellant boiloff rates and can potentially simplify the excursion vehicle thermal design.

Lewis Research Center

National Aeronautics and Space Administration

Cleveland, Ohio, July 2, 1990

\section{Appendix-Glossary}

\begin{tabular}{|c|c|}
\hline ALS & Advanced Launch System \\
\hline LEO & low Earth orbit \\
\hline MEV & Mars excursion vehicle \\
\hline NASA & $\begin{array}{l}\text { National Aeronautics and Space } \\
\text { Administration }\end{array}$ \\
\hline NTO/MMH & nitrogen tetroxide/monomethyl hydrazine \\
\hline$\Gamma \mathrm{S}-\mathrm{C}$ & Space Transportation System-Cargo \\
\hline
\end{tabular}

\section{References}

1. Study Requirements Document-FY 89 Studies, NASA Office of Exploration. Document Number Z-2.1-002, Mar. 3, 1989.

2. Report of the 90-Day Study on Human Exploration of the Moon and Mars. NASA Headquarters, Nov. 1989.

3. Niehoff, J.C.; and Hoffman, S.J.: Piloted Sprint Missions to Mars. The Case for Mars III: Strategies for Exploration-General Interest and Overview, C.R. Stoker, ed.; Univelt Inc., San Diego, CA, 1989, pp. 309-324.

4. Mars Exploration: Split Sprint Mission-Low Earth Orbit Assembly Versus Ground Assembly. NASA Marshall Space Flight Center, Program Development, Apr. 1989.

5. Roberts, B. B.; and Bland, D.: Office of Exploration: Exploration Studies Technical Report, FY 88 Status. Vol. II: Study Approach and Results. NASA TM-4075, 1988.

6. Clark, B.: Artificial Gravity Mars Spaceship. IAF Paper 89-025, Oct. 1989. Presented at the 40th Congress of the International Astronautical Federation, Malaga, Spain, Oct. 7-12, 1989.

7. Analysis of Technologies for Manned Lunar and Mars Missions. (Boeing Aerospace Company, NASA Contract NAS8-36107) NASA CR-183533, 1989.

8. Gordon, S.; and McBride, B.: Computer Program for Calculation of Complex Chemical Equilibrium Compositions, Rocket Performance, Incident and Reflected Shocks, and Chapman-Jouget Detonations. NASA SP-273, 1976.

9. Liquid Rocket Booster (LRB) for the Space Transportation System (STS) Systems Study Performance Review. (Martin Marietta, Document DR-2, NASA Contract NAS8-37136) NASA CR-179324, 1988.

10. Hannum, N.; Berkopec, F.D.; and Zurawski, R.L.: NASA's Chemical Transfer Propulsion Program for Pathfinder. NASA TM-102298, 1989 (Also, AIAA Paper 89-2298, 1989.) 
1I. Tamura, H.; et al.: High Pressure LOX/Heavy Hydrocarbon Fuel Rocket Combustor Investigation. International Symposium on Space Technology and Science, I6th, K. Kondo, ed., Vol. I, Sapporo, Japan, 1988, pp. 265-272.

12. McMillion, R.; Treinen, T.J.; and Stohler, S.L.: Component Evaluations for the XLR-132 Advanced Storable Spacecraft Engine. AIAA Paper $85-1228$, July 1985

13. Craig, M.: Human Exploration Study Requirements. NASA Johnson Space Center, Mar. 1990.

14. Galecki, D.: Ignition and Combustion of Metallized Propellants. AIAA Paper 89-2883, July 1989.

15. VanderWall, E.; et al.: Characterization of Gelled RP-1 Containing Aluminum. Aerojet TechSystems. 1989 JANNAF Propellant
Development and Characterization Subcommittee Meeting, The Johns Hopkins University, Laurel, MD, pp. 77-84.

16. Chew, W.; and Denson, J.R.: Propulsion Systems Hazard Evaluation and Liquid/Gel Propulsion Component Development ProgramFormulation and Characterization of Al/RP-1 Thixotropic Metallized Fuels. TRW Inc., Report 89 AGEL-006; Contract Number DAAH-01-86-C-0114, Oct. 3, 1989

17. Wong, S.; et al.: Disruptive Burning of Aluminum/Carbon Slurry Droplets. Combust. Sci. Technol., vol. 66, 1989, pp. 75-92.

18. Giola, G.; and Dressler, G.A.: Advanced Gel (AGEL) Technology Program. 1989 JANNAF Propulsion Meeting, Vol. II, The Johns Hopkins University, Laurel, MD, 1989, pp. 149-158. 
. 


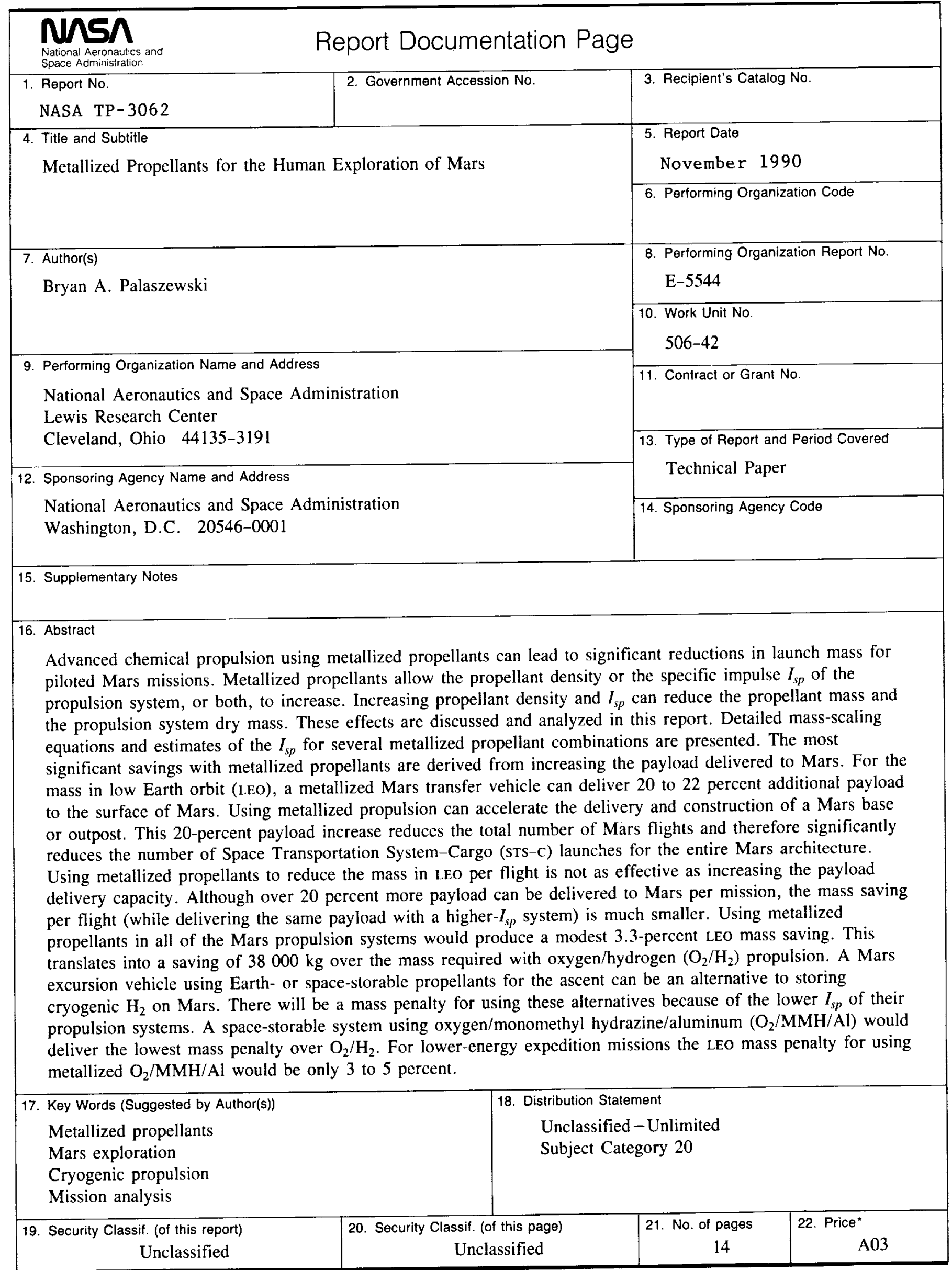


